\title{
Circulation of genetically modified objects in Ukraine
}

\author{
Ushkalov V. ${ }^{1}$, Danchuk V. ${ }^{2}$, Spiridonov V. ${ }^{3}$, Ishchenko L. ${ }^{4}$, \\ Andreyev I. ${ }^{5}$, Kalakailo L. ${ }^{6}$, Novgorodova $0 .^{7}$, Bublyk $0 .{ }^{8}$ \\ ${ }^{1-7}$ National university of biological resources and nature management of Ukraine, Heroiv \\ Oborony Str., 15, Kyiv, 03041, Ukraine; ${ }^{8}$ Poltava state agrarian academy, Skovoroda Str., 1/3, Poltava, \\ 36003, Ukraine; e-mail: ${ }^{1-7}$ ushkalov63@gmail.com, ${ }^{8}$ pdaa@agrosk.poltava.ua
}

The purpose. To analyze results $(2011-2016)$ of investigation in the content of GMO in products of agribusiness industry. Methods. Probes were carried out on the basis of department molecular-biological investigations of the Ukrainian laboratory of quality and safety of products of agrarian and industrial complex of NuBiP of Ukraine. Results. Analysis is made of acting normative deeds in which philosophy of registration and marking GMO in Ukraine are regulated, and also circulation of genetically modified lines of crops in agroindustrial market of Ukraine. Grain and seeds of crops, feedstuffs for animals and food stuffs are probed. Conclusions. In the market of Ukraine, since 2011, they register GM-lines of soya bean (GTS 40-32), rape (RT 73) and corn (Mon 810, Mon 863, NK 603). In the last 2 years they register GM-line of soya bean Mon 89788. GM-line of soya bean GTS 40-3-2 is used for production of feedstuffs for animals and food stuffs.

Key words: ГMO, legislation, soya bean, corn, rape, food stuffs, feedstuffs.

Introduction. Nowadays we are witnessing the rapid development of agricultural biotechnology [1, 2], creating GM lines of plants and productive animals with the desired characteristics (productivity, resistance to herbicides, pests, abiotic and biotic stress factors, etc.). Regarding latest data, about 170 million hectares, which is almost $10 \%$ of the world's suitable arable land, are used to grow GM plants. These are mainly soybeans, corn, rapeseed and cotton [2-4]. Rejecting the safety issues of GM products for human health, which is quite controversial and the discussions around which continue from the very beginning of the creation of GM plants, many other aspects remain $[5,6]$. There is a common public opinion about the need for state control over the cultivation of GM organisms. And the corresponding labeling of products, which includes components obtained with the help of transgenic technologies are needed [6].

The main reason for this need is to ensure the right to choose the use or consumption of products containing GM organisms. According this, GM products in most countries of the world are controlled (e.g. EU Regulations 1829/2003, 1830/2003, 258/27) [6].

Considering Ukraine occupies the leading positions in the world as a producer and exporter of cereals [1], creation of an effective and transparent state system of GMO regulation is extremely important.

Analysis of recent research and publications. Now the main regulatory document on the regulation of the turnover of GMO in Ukraine is the Law of Ukraine "On the State Biosafety System for the Creation, Testing, Transportation and Use of Genetically Modified Organisms» No. 1103 dated May 31, 2007. Adopted with the aim of implementing the main principles in Ukrainian legislation Cartagena Protocol on Biosafety. The adoption of this Law provided for the state regulation of the relations between producers, sellers (suppliers), developers, researchers, scientists and consumers of genetically modified organisms and products manufactured by technologies, preclude their development, creation, testing, research, transportation, import, export, placing on the market, release into the environment and use in Ukraine with the provision of biological and non-personal security [7].

According to this Law, the powers to control and regulate GMOs are distributed among the main executive authorities: Cabinet of Ministers, the Ministry of Education and Science, Ministry of Ecology and Natural Resources, Ministry of Health and Ministry of Agrarian Policy and Food. Regarding this, such a redistribution of authority, GMO registration is carried out by: in the state register of plant varieties created on 
the basis of GMOs [8] (maintained by the Ministry of Agrarian Policy), the State Register of Cosmetic and Medicinal Products GMO [9] (maintains the Ministry of Health of Ukraine) and the State Register of GMOs of food, feed, fodder additives and veterinary preparations containing such organisms or obtained with their use (conducted by State Service of Ukraine for Food Safety and Consumer Protection) [10].

In accordance with the provisions adopted in the Law of Ukraine since September 20, 2015, amendments to the Law of Ukraine "On the State Biosafety System for the Creation, Testing, Transportation and Use of Genetically Modified Organisms" 1602-VII of July 22, 2014 "On Making amendments to some legislative acts of Ukraine with respect to food products ".

The general objective of this law is to harmonize Ukraine's legislation with EU legislation on food safety and quality, as well as on GMOs - the implementation of European principles for the regulation of GMOs, in particular regarding the registration of sources of GMOs and not the products made from them, were introduced amendments to the decisions of the Cabinet of Ministers on the registration of GMOs.

However, there is practically no effective mechanism for regulating the turnover of GMOs in Ukraine. Despite the existence of the aforementioned state registers, at present only one product is registered in Ukraine and it is permitted in the production of feed for farm animals - soybean meal GM 40-3-2 GMO, the registration of which is valid until 2018. There are other GMOs on the Ukrainian market, in particular GM soybean, corn and rape lines [3]

Regarding Decision of the Cabinet of Ministers of Ukraine No. 468 of May 13, 2009. With the amendments "On approval of the Procedure for labeling food products containing genetically modified organisms or produced with their use and put into circulation", the manufacturer is obliged to provide the consumer with reliable information on the content of GMOs in products (or the use of GMOs in the production of products) by the way of marking such goods.

According to this decree, information should be indicated on the label with the appropriate labeling, if food products contain more than $0,9 \%$ of GMO. The same regulation regulates, if the product does not contain GMO or its content is less than $0,1 \%$, then the manufacturer can voluntarily affix the marking "Without GMOs". At the same time, the Ministry of Health of Ukraine issued Order No. 971 of 09.11.2010. Approved "List of food products in respect of which the control of the content of genetically modified organisms is mandatory".

The aim is to analyze the results of the research of content of GMOs in agro-industrial products for years 2011-2016.

Materials and methods. Researches were conducted at the department of molecular biological research Ukrainian laboratory of quality and safety of agricultural products of NULES for 2011-2016 years.

The research was conducted according to GOST ISO 21569: 2008 Food products. Methods for the detection of genetically modified organisms and products with their content. Qualitative methods based on nucleic acid analysis (ISO 21569: 2005, IDT) DSTU ISO 21571: 2008 Food products. Methods for the detection of genetically modified organisms and products with their content. Nucleic acid extraction (ISO 21571: 2005, IDT) DSTU ISO 21570: 2008 Food products. Methods for the detection of genetically modified organisms and products with their content.

Quantitative methods based on nucleic acid analysis ISO 21570: 2005, IDT; CEN / TS 15568 Foodstuffs Methods of analysis for the detection of genetically modified organisms and derived products - Sampling strategies.

Results of the research. The study of the qualitative and quantitative content of GMOs in the Ukrainian Laboratory of Quality and Safety of Agricultural Products (ULQSAP) began in 2005, according to now, considerable experience has been accumulated in this direction [3]. ULQSAP is an associate member of the European Association of Laboratories for GMO Research in Food and Feed (European Union Reference Laboratory for GM Food and Feed) and regularly participates in interlaboratory rounds held by this association on identification and quantification of GM-lines of agricultural plants. In addition, the employees of ULQSAP was developed, tested and implemented in the practical work of diagnostic laboratories "Diagnostic set" GMO-PCR "for the detection of genetically modified organisms of plant origin by polymerase 
chain reaction (Registration Certificate No. BB-00057-06- 09 from 03.11.2009 to 02.11.2014). For the period from 2011. By 2016, 5,560 samples of various origins were examined for GMO content (Table 1).

Table 1. The range of samples analyzed for GMO content 2016-2011 years

\begin{tabular}{|l|c|c|c|c|c|c|}
\hline Type of product & 2016 & 2015 & 2014 & 2013 & 2012 & 2011 \\
\hline Corn & 139 & 60 & 1448 & 555 & 106 & 120 \\
\hline Soy & 128 & 171 & 330 & 179 & 64 & 36 \\
\hline Rape (canola) & 47 & 30 & 83 & 133 & 24 & 34 \\
\hline $\begin{array}{l}\text { Seeds and other } \\
\text { grains agricultural } \\
\text { crops }\end{array}$ & 56 & 26 & 239 & 88 & 72 & 68 \\
\hline Dietary supplements & 32 & 79 & 66 & 75 & 106 & 101 \\
\hline Food & 69 & 33 & 76 & 131 & 134 & 145 \\
\hline Animal feed & 9 & 22 & 1 & 7 & 12 & 15 \\
\hline Other & 1 & 2 & 7 & 1 & 0 & 0 \\
\hline Total & $\mathbf{5 2 1}$ & $\mathbf{4 6 8}$ & $\mathbf{2 2 5 0}$ & $\mathbf{1 1 6 9}$ & $\mathbf{5 1 8}$ & $\mathbf{4 9 8}$ \\
\hline
\end{tabular}

According to Table. 1, the main part of the samples under study is the seeds and grain of agricultural crops. Soy, maize and rapeseed, the cultivation of which constitutes the "lion's" share of GM plants, according to ULQSAP and many laboratories, of course, in the Ukrainian market [3]. Accordingly, the lack of an effective seed registration mechanism for GM plants forces farmers, grain storage enterprises and grain traders to control the content of GMOs in raw materials throughout the entire chain.

Also, attention should be paid to reducing the proportion of food research from 2011. Such a phenomenon can be explained by the fact that the first edition of the CMU Resolution No. 468 dated May 13, 2009 "On Approval of the Procedure for Labeling Food Products, genetically modified organisms or produced with their use and put into circulation "required the mandatory labeling of" Without GMOs "and, accordingly, the study of all food products on the content of GMOs.

Accordingly, at this time there is a period when the study came products that potentially cannot contain plant DNA (eggs, salt, sugar, bottled water, etc.). Such a requirement has led to mass discontent among food manufacturers and distributors, as it involves significant and often unreasonable costs. Therefore, on July 1, 2009, the above-mentioned Resolution amended that the inscription "Without GMO" may be affixed to the product label on a voluntary basis. Given this, since July 2009, the bulk of the food coming to the study is those that belong to the "List of food products for which the control of the content of genetically modified organisms" is approved, approved by the Ministry of Health of Ukraine. Studies have been conducted on the detection of GMOs in samples (Fig. 1). 


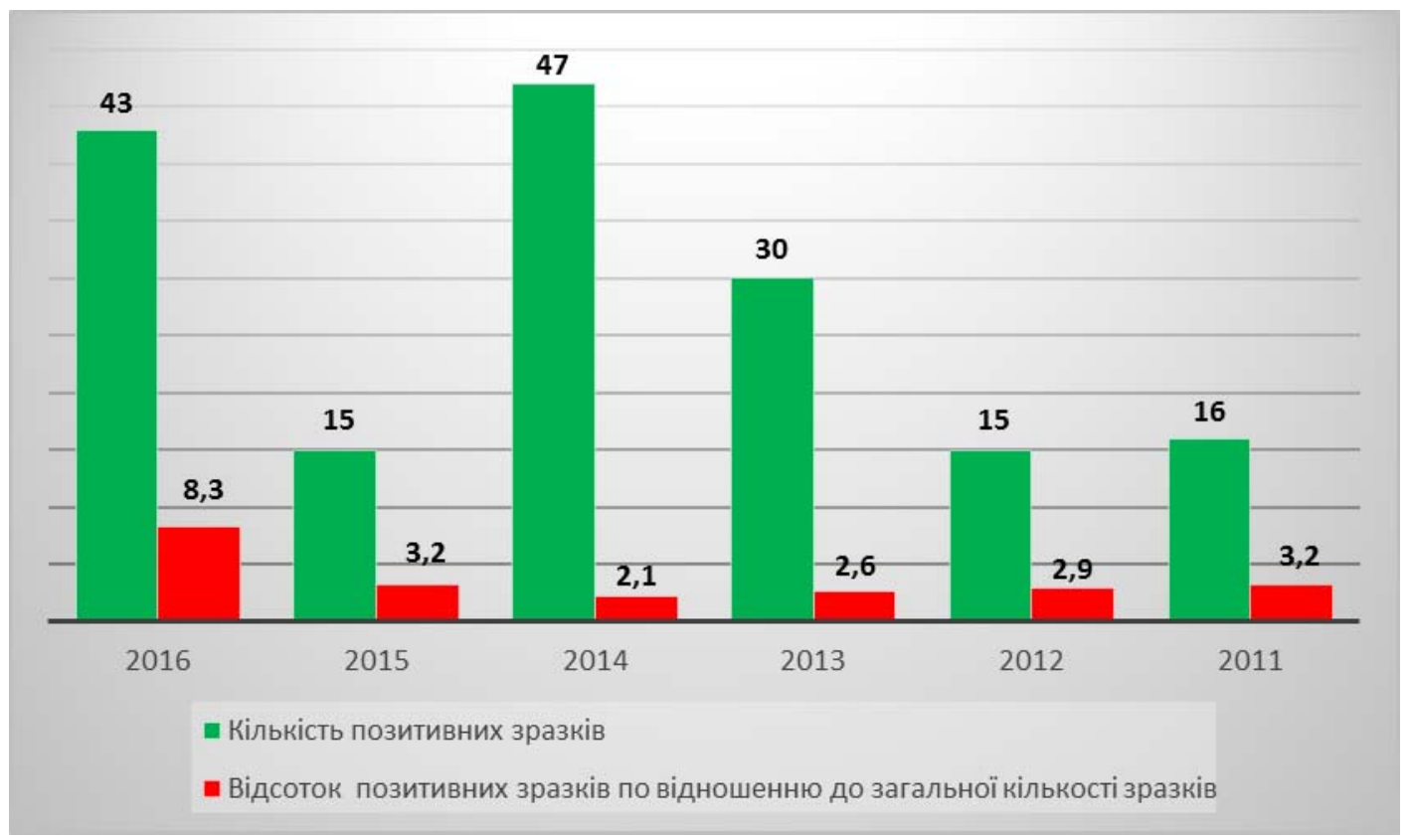

Fig. 1. The number of positive samples on GMOs over the period.

The greatest amount of GMOs was found in soybeans, less in rape, corn, animal feeds, and the least in food products (Fig. 2).

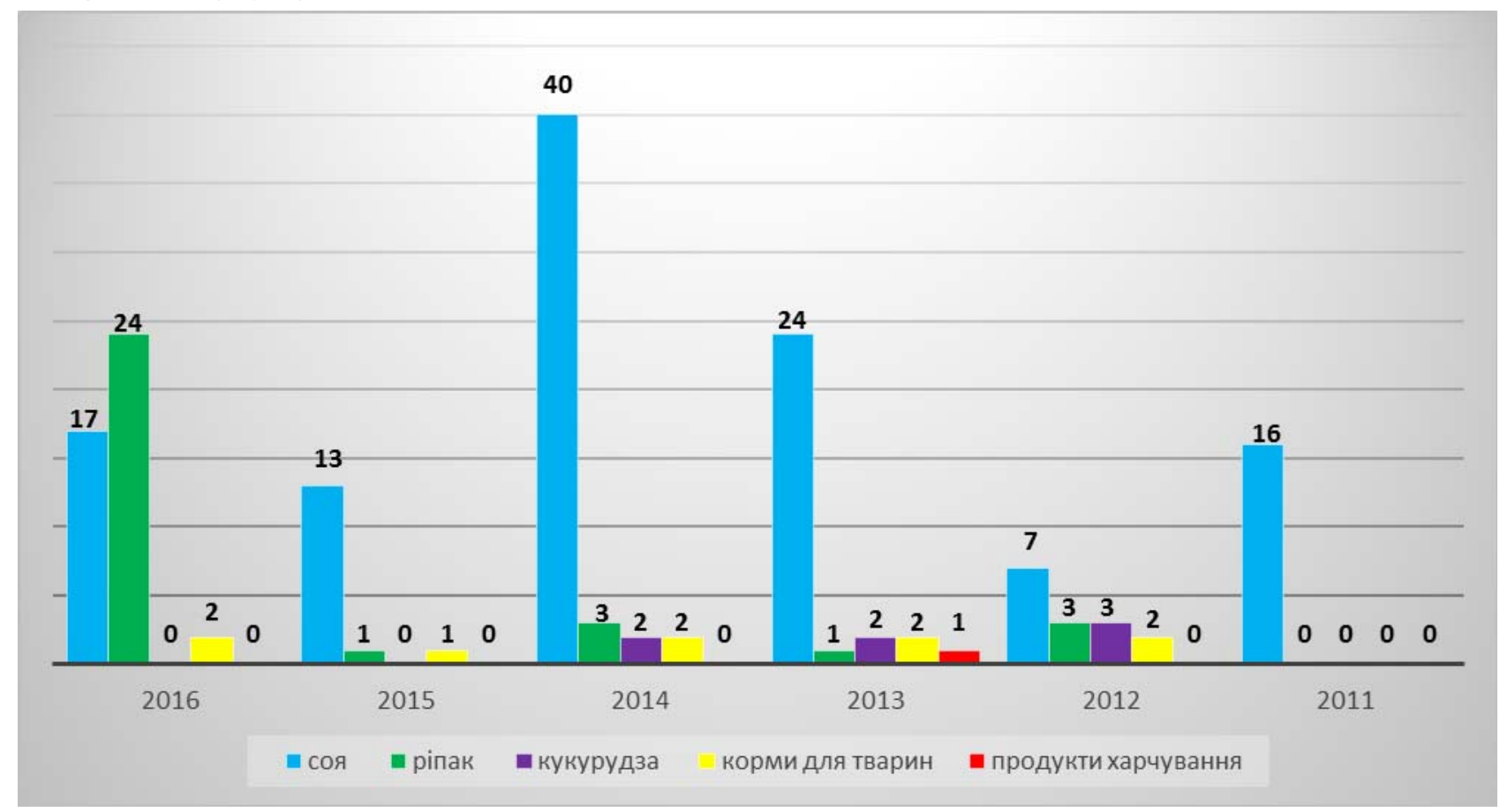

Fig. 2. Description of samples in which detected GMOs.

An important component of the study of GMO content is the identification of GM lines, since it allows us to understand which particular lines of a GMO plant are in circulation in the agro-industrial market, and in the case of multicomponent samples, the ability to trace which GM lines enter the production of products food or feed for animals. However, it should be noted that the cost of identifying GM lines is rather high and, as a rule, it is only needed for enterprises that eximporting grain from EU countries [2].

Thanks to the long-term work, now in the ULQSAP it is possible to identify 17 lines of GM maize, 7 lines of GM rape and 5 lines of GM soya. All specimens in which GMOs are detected must be identified (Table 2). 
Table 2 - Identification of GM events of samples in which was found GMO.

\begin{tabular}{|c|c|c|c|}
\hline Year & Sample & GM event & Number of samples \\
\hline \multirow{4}{*}{2016} & \multirow[t]{2}{*}{ Soy } & GTS 40-3-2 & 15 \\
\hline & & MON 89788 & 2 \\
\hline & Seeds of soybean & GTS 40-3-2 & 2 \\
\hline & Rape & GT 73 & 24 \\
\hline \multirow[t]{3}{*}{2015} & Soy & GTS 40-3-2 & 13 \\
\hline & Seeds of soybean & GTS 40-3-2 & 1 \\
\hline & Rape & GT 73 & 1 \\
\hline \multirow[t]{6}{*}{2014} & Soy & GTS 40-3-2 & 40 \\
\hline & Feed for birds & GTS 40-3-2 & 1 \\
\hline & Feed for pigs & GTS 40-3-2 & 1 \\
\hline & Rape & GT 73 & 3 \\
\hline & \multirow[t]{2}{*}{ Corn } & NK 603 & 1 \\
\hline & & Mon 810 & 1 \\
\hline \multirow[t]{5}{*}{2013} & Soy & GTS 40-3-2 & 24 \\
\hline & Feed yeast & GTS 40-3-2 & 2 \\
\hline & Milk puder & GTS 40-3-2 & 1 \\
\hline & Rape & GT 73 & 1 \\
\hline & Corn & NK 603 & 2 \\
\hline \multirow[t]{5}{*}{2012} & Soy & GTS 40-3-2 & 7 \\
\hline & Seeds of soybean & GTS 40-3-2 & 2 \\
\hline & Rape & GT 73 & 3 \\
\hline & \multirow[t]{2}{*}{ Corn } & Mon 863 & 2 \\
\hline & & Mon 810 & 1 \\
\hline 2011 & Soy & GTS 40-3-2 & 16 \\
\hline
\end{tabular}

Data tab 2 testify to the long-term availability of such GM-lines in the agro-industrial market of Ukraine: soybeans - GTS 40-3-2; rape - GT 73; corn - Mon 810, NK603, Mon 863. In recent years, the GM-line of soybean MON 89788 has been identified. The vast majority of GM lines in circulation in Ukraine (soybean GTS 40-3-2 and MON 89788, rape GT 73, maize NK 603) are resistant to glyphosate, the active substance of many registered in our state, systemic herbicides. Growing glyphosate-resistant GM-lines of plants greatly reduces the cost of the final product, since it requires less expenditure to control weeds. GM corn lines Mon 810 and Mon 863 have resistance to corn pests [2, 3].

For a better understanding of the GM plant turnover, the results of the identification of GM lines should be analyzed together with a quantitative estimate of the GMO content. Here the situation with GM-corn draws attention. Although we get high values (more than 10\%) for quantitative determination of the content of GMOs in soybeans and rape, then the content of GMOs in any of the samples of maize did not exceed $1 \%$.

In addition, GMO corn has been identified was not over the past 2 years. As for the identification of GM lines in multicomponent samples, in particular, food additives [3], as shown in Table. 2, in the production of food and animal feed GM-line soybean GTS 40-3-2.

\section{Conclusions}

An analysis of the results of the study on the presence of GMOs in products of the agro-industrial complex for years 2011-2016 evidences about the availability of genetically modified crops in Ukraine: soybeans, corn and rape lines.

Separate lines of GM plants (soybean GTS 40-3-2, rape lines GT 73) are stable are highly available in the agro-industrial market of Ukraine, and some only appear (soybean MON 89788).

The situation with GM maize is ambiguous and needs to be clarified. In accordance with testified results of researches regarding undeniable presence of GM plants in the agro-industrial market of Ukraine, we consider the primary task of ensuring an effective mechanism of state registration of the seed material, which will further allow us to trace the use of the raw material in the production of feed for animals, foodstuffs, medical and veterinary drugs and others. 


\section{Bibliography}

1. Hadzalo Ya.M. Hladii M.V., Sabluk P.T. (2016). Ahrarnyi potentsial Ukrainy: monohrafiia. Kyiv: Ahrarna nauka. $332 \mathrm{~s}$. [In Ukrainian].

2. Martin H.M., Durr D., Smith M. et al. (2017). Analysis of GMO food products companies: financial risks and opportunities in the global agriculture industry. African J. of Economic and Sustainable Development. T. 6. №. 1. P. 1-17.

3. Ushkalov V.O., Danchuk V.V., Baranov Yu.S. et al. (2016). Monitorynh bioresursiv i produktsii ahropromyslovoho kompleksu na pokaznyky yakosti ta bezpeky yak skladova kontseptsii VOOZ-MEB «Hlobalne zdorovia». Veterynarna medytsyna. T. 102. S. 219-223. [In Ukrainian].

4. Wunderlich S., Gatto K.A. (2015). Consumer Perception of Genetically Modified Organisms and Sources of Information. Adv. Nutr. V. 6. P. 842-851.

5. Ayyadurai V.A.S., Deonikar P. (2015). Do GMOs Accumulate Formaldehyde and Disrupt Molecular Systems Equilibria? Systems Biology May Provide Answers. Agricultural Sciences. T. 6. № 07. P. 630-662.

6. Aarts H.J., J.P. van Rie, Kok E.J. (2002). Traceability of genetically modified organisms. Expert Rev Mol Diagn. V. 2(1). P. 69-76.

7. Pro derzhavnu systemu biobezpeky pry stvorenni, vyprobuvanni, transportuvanni ta vykorystanni henetychno modyfikovanykh orhanizmiv. Vidomosti Verkhovnoi Rady Ukrainy (VVR), 2007. N 35. S. 484. [In Ukrainian].

8. Deiaki pytannia provedennia aprobatsii (vyprobuvannia) ta reiestratsii henetychno modyfikovanykh orhanizmiv sortiv silskohospodarskykh roslyn: Postanova Kabinetu Ministriv Ukrainy vid 23 lypnia 2009 r. N 808 r. zi zminamy. Uriadovyi kurier. Ofitsiine vydannia vid 19.08.2009, № 150. [In Ukrainian].

9. Pro zatverdzhennia Poriadku derzhavnoi reiestratsii kosmetychnykh ta likarskykh zasobiv, yaki mistiat henetychno modyfikovani orhanizmy abo otrymani z yikh vykorystanniam: Postanova Kabinetu Ministriv Ukrainy vid 18 liutoho 2009 r. N 114 r. zi zminamy. Uriadovyi kurier. Ofitsiine vydannia vid 26.02.2009, № 35. [In Ukrainian].

10. Pytannia zabezpechennia realizatsii statti 7 Zakonu Ukrainy «Pro derzhavnu systemu biobezpeky pry stvorenni, vyprobuvanni, transportuvanni ta vykorystanni henetychno modyfikovanykh orhanizmiv»: Postanova Kabinetu Ministriv Ukrainy vid 12 zhovtnia 2010 r., № 919 zi zminamy. Uriadovyi kurier. Ofitsiine vydannia vid 20.10.2010, № 195. [In Ukrainian]. 